\title{
Experimental Study on Mechanical Properties of Marine Sand and Seawater Concrete
}

\author{
Ming CUI ${ }^{1, a}$, Ji-Ze MAO ${ }^{1, b,{ }^{*}}$, Dao-Guang JIA ${ }^{1, c}$, Ben $\mathrm{LI}^{1, \mathrm{~d}}$ \\ ${ }^{1}$ Collage of Aerospace and Civil Engineering, Harbin Engineering University, Harbin 150001, China \\ acloudtion@163.com, ’maojize@hrbeu.edu.cn, cjiadaoguang@163.com, dsktm1@163.com \\ ${ }^{*}$ Corresponding author
}

Keywords: Concrete, Marine Sand, Seawater, Mechanical Property.

\begin{abstract}
As Chinese development of marine resources intensifies in recent years, more and more offshore platforms and buildings, island structures are under construction. However, concrete aggregate and freshwater resources which are used to mix concrete are usually limited in coastal areas or on the islands. This paper concentrates on marine sand and seawater concrete which use marine sand instead of river sand as concrete fine aggregate and mix with seawater instead of freshwater. Also mechanical properties including compressive strength, failure mode, elasticity modulus, relationship of stress-strain were compared and analyzed between marine sand and seawater concrete and ordinary concrete.
\end{abstract}

\section{Introduction}

Since the reform and opening-up policy, China's rapid economic development, especially along coastland rises rapidly, so the amount of concrete grows fast in coastal areas, its output becomes nearly 2 billion cubic meters in 2013, and its output cost nearly 600 billion yuan. China is the largest manufacturing and consuming concrete country in the world. The cement, sand and gravel aggregate, admixtures, concrete equipment production scale rank the first in the world too [1]. In particular, a huge amount of sand, more than 3 billion tons of sand was used in construction of concrete only in 2013, which boosted the largest amount of China's manufacturing logistics. With the increasing amount of sand used in construction, the resources of river sand as the main source of construction sand are reducing, but at present the majority of China use river sand still. River sand is a natural resource that is also a slow regenerative resource [2]. Due to the surge in demand, there has been rapid reduction even disappearance of river sand in the case of the original river sand-rich areas. Moreover concrete aggregate and freshwater resources which are used to mix concrete are usually limited in coastal areas or on the islands, and the cost of transportation for these materials is quite high. Thus this paper proposes to use marine sand instead of river sand as concrete fine aggregate and mix with seawater instead of freshwater to produce concrete, and it is very easy to obtain marine sand and seawater whose price and transportation is more affordable for marine constructions [3]. So far there has been few study about the marine sand and seawater concrete. So for the application of marine sand and seawater concrete, its mechanical properties should be studied. There are some experiments been done to research the mechanical properties of marine sand concrete and seawater concrete respectively [4-6], these results can be used as a reference.

\section{Experimental Programs}

An experimental study was undertaken to investigate the effects of marine sand and seawater used for mixing and seawater for curing on concrete. The experimental items include the compressive strength (up to 28 days), failure mode, elasticity modulus and relationship of stress-strain [7-13].

Marine sand and river sand are different in some physical characteristics. Fig.1 shows the grading curves of fine aggregates, marine sand is fine sand and its surface is relatively smooth, diameter focusing on $0.315 \mathrm{~mm}$ area up to $84 \%$, and river sand is medium sand and its surface is relatively rough, diameter no obvious focusing area, and there are large stone-like particles in river sand. 


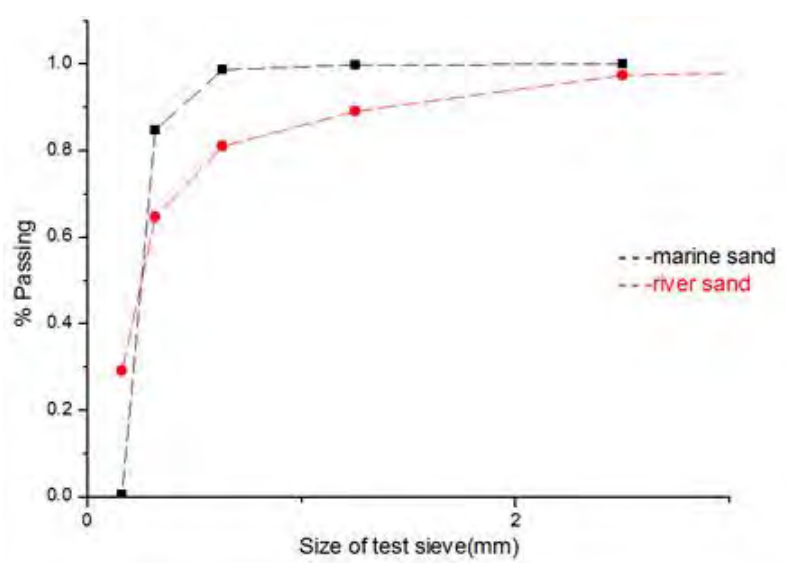

Fig. 1 Grading Curves of Fine Aggregates

\section{Experiments on Compressive Strength}

Table 1 and Table 2 show the dosage adopted for concrete production that are used to study the compressive strength of different W/C ratio. Among them the specimens of marine sand and seawater concrete (numbered beginning with $\mathrm{S}$ ) are cured by seawater and the specimens of ordinary concrete (numbered beginning with $\mathrm{N}$ ) are cured by fresh water. Because of the different $\mathrm{W} / \mathrm{C}$ ratio, two kinds of concrete specimens are divided into S1-S4 and N1-N4 groups, each group contains 6 concrete cubes whose size is $100 \mathrm{~mm} * 100 \mathrm{~mm} * 100 \mathrm{~mm}$. this experimental procedure was carried out according to Standard for Test Method of Mechanical Properties on Ordinary Concrete [8].

Tab. 1 Ordinary Concrete Mixture Proportions

\begin{tabular}{c|c|c|c|c|c}
\hline Specimens & $\begin{array}{c}\text { Cement } \\
{\left[\mathrm{kg} / \mathrm{m}^{3}\right]}\end{array}$ & $\begin{array}{c}\text { Fresh water } \\
{\left[\mathrm{kg} / \mathrm{m}^{3}\right]}\end{array}$ & $\begin{array}{c}\text { River sand } \\
{\left[\mathrm{kg} / \mathrm{m}^{3}\right]}\end{array}$ & $\begin{array}{c}\text { Coarse aggregate } \\
{\left[\mathrm{kg} / \mathrm{m}^{3}\right]}\end{array}$ & W/C ratio \\
\hline N1 & 306 & 245 & 795 & 1054 & 0.80 \\
\hline N2 & 392 & 245 & 674 & 1099 & 0.63 \\
\hline N3 & 481 & 245 & 606 & 1078 & 0.51 \\
\hline N4 & 612 & 245 & 494 & 1049 & 0.40 \\
\hline
\end{tabular}

Tab. 2 Marine Sand and Seawater Concrete Mixture Proportions

\begin{tabular}{c|c|c|c|c|c}
\hline Specimens & $\begin{array}{c}\text { Cement } \\
{\left[\mathrm{kg} / \mathrm{m}^{3}\right]}\end{array}$ & $\begin{array}{c}\text { Seawater } \\
{\left[\mathrm{kg} / \mathrm{m}^{3}\right]}\end{array}$ & $\begin{array}{c}\text { Marine sand } \\
{\left[\mathrm{kg} / \mathrm{m}^{3}\right]}\end{array}$ & $\begin{array}{c}\text { Coarse aggregate } \\
{\left[\mathrm{kg} / \mathrm{m}^{3}\right]}\end{array}$ & W/C ratio \\
\hline S1 & 306 & 245 & 795 & 1054 & 0.80 \\
\hline S2 & 392 & 245 & 674 & 1099 & 0.63 \\
\hline S3 & 481 & 245 & 606 & 1078 & 0.51 \\
\hline S4 & 612 & 245 & 494 & 1049 & 0.40 \\
\hline
\end{tabular}

\section{Experiments on Failure Mode, Elasticity Modulus and Relationship of Stress-strain}

Table 3 and Table 4 show the dosage adopted for concrete production that are used to study the failure mode, elasticity modulus and relationship of stress-strain. Among them the specimens of marine sand and seawater concrete (expressed as SY) are cured by seawater and the specimens of ordinary concrete (expressed as NY) are cured by fresh water. Each group contains 6 concrete prisms whose size is $100 \mathrm{~mm} * 100 \mathrm{~mm} * 300 \mathrm{~mm}$.

This experimental procedure was carried out according to Standard for Test Method of Mechanical Properties on Ordinary Concrete [8] and some previous relevant experiments. The experimental process is shown in Fig.2. When the pressure machine works, the pressure sensor collect information 
of stress and the strain gauge collect information of strain, the information of stress and strain through the data acquisition are saved in computer until the specimen is destroyed.

Tab. 3 Ordinary Concrete Mixture Proportions

\begin{tabular}{c|c|c|c|c|c|c}
\hline Specimen & $\begin{array}{c}\text { Cement } \\
{\left[\mathrm{kg} / \mathrm{m}^{3}\right]}\end{array}$ & $\begin{array}{c}\text { Freshwater } \\
{\left[\mathrm{kg} / \mathrm{m}^{3}\right]}\end{array}$ & $\begin{array}{c}\text { River sand } \\
{\left[\mathrm{kg} / \mathrm{m}^{3}\right]}\end{array}$ & $\begin{array}{c}\text { Coarse } \\
\text { aggregate } \\
{\left[\mathrm{kg} / \mathrm{m}^{3}\right]}\end{array}$ & $\begin{array}{c}\text { water reducing } \\
\text { agent } \\
{\left[\mathrm{kg} / \mathrm{m}^{3}\right]}\end{array}$ & $\begin{array}{c}\text { W/C } \\
\text { ratio }\end{array}$ \\
\hline $\mathrm{NY}$ & 360 & 216 & 787 & 1040 & 2.628 & 0.60 \\
\hline
\end{tabular}

Tab. 4 Marine Sand and Seawater Concrete Mixture Proportions

\begin{tabular}{c|c|c|c|c|c|c}
\hline Specimen & $\begin{array}{c}\text { Cement } \\
{\left[\mathrm{kg} / \mathrm{m}^{3}\right]}\end{array}$ & $\begin{array}{c}\text { Seawater } \\
{\left[\mathrm{kg} / \mathrm{m}^{3}\right]}\end{array}$ & $\begin{array}{c}\text { Marine } \\
\text { sand } \\
{\left[\mathrm{kg} / \mathrm{m}^{3}\right]}\end{array}$ & $\begin{array}{c}\text { Coarse } \\
\text { aggregate } \\
{\left[\mathrm{kg} / \mathrm{m}^{3}\right]}\end{array}$ & $\begin{array}{c}\text { water reducing } \\
\text { agent } \\
{\left[\mathrm{kg} / \mathrm{m}^{3}\right]}\end{array}$ & $\begin{array}{c}\text { W/C } \\
\text { ratio }\end{array}$ \\
\hline $\mathrm{SY}$ & 360 & 216 & 747 & 1077 & 2.7 & 0.60 \\
\hline
\end{tabular}

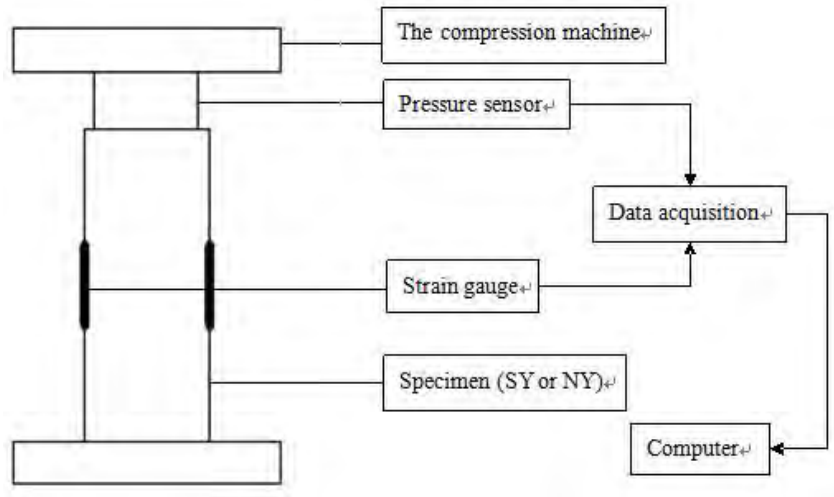

Fig. 2 Experimental Process of Relationship between Stress and Strain of Concrete

\section{Results and Discussion}

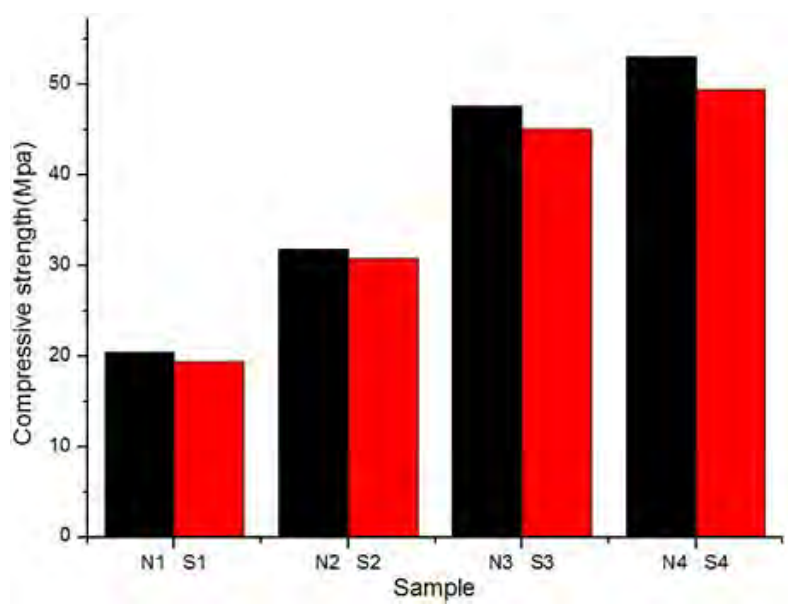

Fig.3 Compressive Strength

Fig. 3 shows the compressive strength of marine sand and seawater concrete and ordinary concrete. The compressive strength of marine sand and seawater concrete cured in seawater is lower than that of ordinary concrete cured in fresh water, when with the same mixture proportions. When W/C ratio is $0.80,0.63,0.51$ and 0.40 , the compressive strength of marine sand and seawater concrete cured in seawater respectively decrease by about $5 \%$. Based on the existing research [4-6], these results are caused by two reasons. The main reason is that marine sand and river sand are different in some 
physical characteristics, as mentioned above marine sand is more fine and its surface is relatively smooth, this reason affects greatly compressive strength of concrete. The secondary reason is that chloride ion in marine and seawater has an impact on compressive strength of concrete in some way.

Fig.4 shows the failure mode of marine sand and seawater concrete and ordinary concrete. After ordinary concrete reaching the ultimate compressive strength, there are four obvious long cracks along the pressure line on the surface of concrete, one of them is longer and basically cross the specimen. But the performance of the marine sand and seawater concrete is different, there are more short cracks on the surface, which leads that a part of concrete is crushed and fall down from concrete. Based on the existing research results, the difference of marine sand and river sand in physical characteristics leads the difference in strength, but not failure mode obviously [4,6], so this difference in failure mode may cause by chloride ion in marine and seawater.

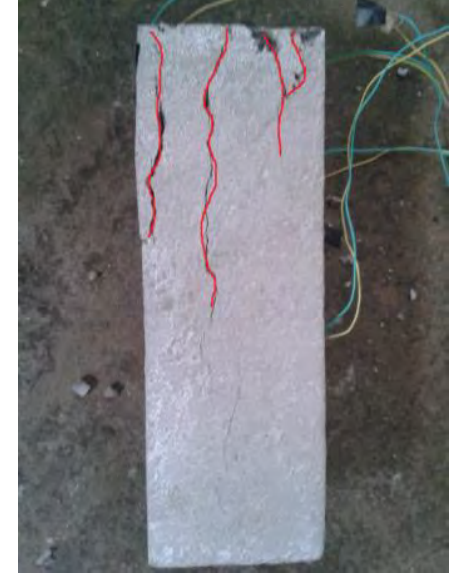

Ordinary Concrete

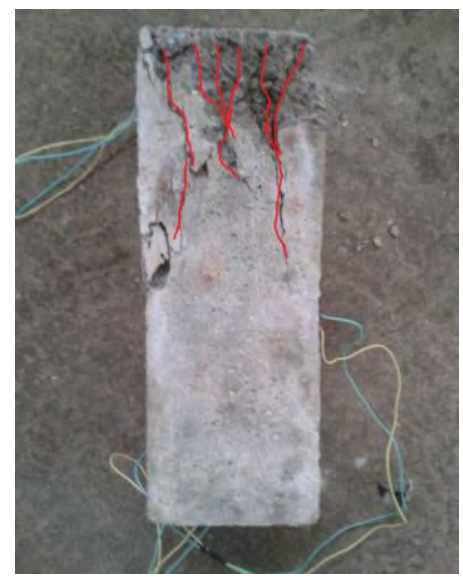

Marine Sand and Seawater Concrete

Fig.4 Failure Mode of Two Kinds of Concrete

Fig.5 shows the relationship between stress and strain of marine sand and seawater concrete and ordinary concrete. The tendencies of compressive relationship of stress-strain of two kinds of concrete are similar, but both the ultimate stress and the rate of change have significant differences which are very important in the use of concrete [14]. These results may be due to the different diameter of marine sand and river sand, and chloride ion in marine and seawater.

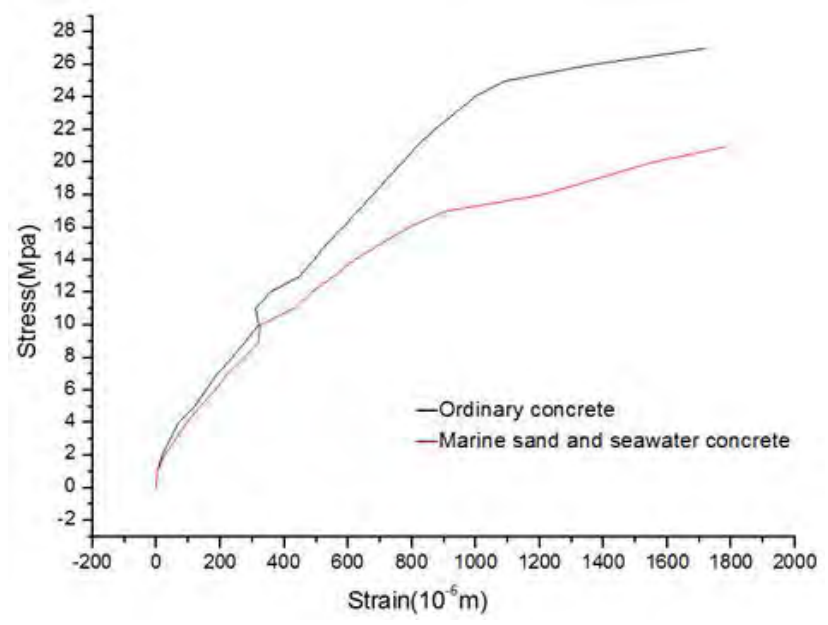

Fig.5 Relationship of Stress-strain

Table 5 shows the elasticity modulus of marine sand and seawater concrete and ordinary concrete. The elasticity modulus of marine sand and seawater concrete decreases by $9 \%$ than that of ordinary concrete. Based on the existing research, these results may be due to the chloride ion in marine and seawater, with the hydration of cement, sodium chloride crystals and its volume expands, resulting in internal concrete cracking, which leads the change of the elasticity modulus [15-16]. 
Tab. 5 Elasticity Modulus of Concrete

\begin{tabular}{c|c}
\hline Specimen & Elasticity modulus[Mpa] \\
\hline NY & 3.3 \\
\hline SY & 3.0 \\
\hline
\end{tabular}

\section{Conclusions}

According to the experimental programs performed in this study that compares the mechanical properties of marine sand and seawater concrete and that of ordinary concrete, the following conclusions can be drawn: compressive strength and elasticity modulus of marine sand and seawater concrete cured in seawater decrease than that of ordinary concrete cured in fresh water, failure mode of two kinds of concrete have significant differences too. These results may be due to the different diameter of marine sand and river sand, and chloride ion in marine and seawater, which change the internal relation of marine sand and seawater concrete compared with ordinary concrete, and further changes the mechanical properties of concrete itself.

\section{Acknowledgement}

This research was financially supported by National Natural Science Foundation of China (50908059), Natural Science Foundation of Heilongjiang Province of China (E201415), and the Fundamental Research Funds for the Central Universities of China (HEUCFZ1103 and HEUCF130215).

\section{References}

[1]ZHANG Yong, The Use of Coastal Sea Sand and Research Issues, J. Sichuan Building. 3 (2006) 129-130.

[2]LENG Fa-guang, DING Wei, The Key Points Sand Concrete Application of Technology, J. Construction Technology. 338 (2011) 97-100.

[3]TIAN Mei-ling, Review of Research Durability of Sea Sand Concrete, Concrete. 11 (2010) $117-127$.

[4]J. Limeira, M. Etxeberria, L. Agullo, D. Molina, Mechanical and Durability Properties of Concrete Made with Dredged Marine Sand, J. Construction and Building Materials. 25 (2011) 4162-4174.

[5]LIN Jun-zhe, CHEN Jian-bin, HE Zhi-min, Study on the Properties of Sea Sand Concrete, C. Mechanic Automation and Control Engineering (MACE), 2011 Second International Conference on. (2011) 3584-3587.

[6]S. K. Kaushik, S. Islam, Suitability of Sea Water for Mixing Structural Concrete Exposed to a Marine Environment, J. Cement \& Concrete Composites. 17 (1995) 177-185.

[7]Kato, Kiyoshi, Microcracks and Evaluation of Mechanical Properties of Plain Concrete, J. Doboku Gakkai Rombun-Hokokushu/Proceedings of the Japan Society of Civil Engineers. 208 (1972) 121-136.

[8]RONG Jun-ming, LU Jian-wen, Standard for Test Method of Mechanical Properties on Ordinary Concrete, China, 2003.

[9]TAN Bin, Research on Stress-strain Curves of Reactive Powder Concrete under Uniaxial Compression, D (2007) 14-23.

[10]LI Wei, WANG Xiao-chun, Experimental Study on the Mechanical Properties of the Crumb Rubber Concrete, J. Advanced Materials Research. 645 (2013) 172-175. 
[11]D.Watstein, Effect of Straining Rate on the Compressive strength and Elastic Proterties of Concrete, J. Journal of ACI. 40 (1953) 102-108.

[12]Hughes BP Gregory R, Concrete Subjected to High Rates of Loading in Compression, J. Magazine of Concrete Research. 12 (1972) 237-245.

[13]McCoy, W. J., Water for Mixing and Curing Concrete. In Significance of Test and Properties of Concrete and Concrete Aggregates, J. ASTM STP. 169 (1956) 352-357.

[14]Dubois V, Abriak NE, Zentar R, Ballivy G, The Use of Marine Sediments as a Pavement Base Material, J. Waste Manage. 2 (2009) 74-82.

[15]Povindar K. Mehta, Harvey H. Haynes, Durability of Concrete in Seawater, J. Journal of the Structural Division. 8(1975) 1679-1686.

[16]Nishibayashi, S. et al., Durability of Concrete in Sea Water, J. ACI Publication. 2 (1980) 351-378. 